\begin{tabular}{lllllllllllllllll}
$\mathrm{S}$ & $\mathrm{T}$ & $\mathrm{U}$ & $\mathrm{D}$ & $\mathrm{I}$ & $\mathrm{A}$ & $\mathrm{T}$ & $\mathrm{E}$ & $\mathrm{M}$ & $\mathrm{A}$ & $\mathrm{T}$ & $\mathrm{Y}$ & $\mathrm{C}$ & $\mathrm{Z}$ & $\mathrm{N}$ & $\mathrm{E}$ \\
\hline
\end{tabular}

STUDIA Z PRAWA WYZNANIOWEGO

Tom $21-2018$

DOI: https://doi.org/10.31743/spw.186

JERZY NIKOŁAJEW ${ }^{*}$

\title{
STATUS KAPELANÓW DUSZPASTERSTW SPECJALNYCH W UKRAIŃSKIM SYSTEMIE PRAWNYM
}

\section{Streszczenie}

Ukraińskie duszpasterstwo wojskowe posiada najbardziej rozwinięte struktury organizacyjne. Wpływ na to miały wydarzenia związane z rosyjską aneksją Krymu oraz wojną hybrydową w Donbasie. Także duszpasterstwo więzienne zostało zorganizowane w oparciu o struktury zakładów karnych i aresztów śledczych. Natomiast duszpasterstwo policyjne wymaga wprowadzenia nowych rozwiązań legislacyjnych. Poza tym Kościół greckokatolicki na Ukrainie utworzył własne struktury diecezjalne dla potrzeb duszpasterstw specjalnych a pozostałe wspólnoty religijne kapelaństwo $\mathrm{w}$ wojsku, policji i więziennictwie zorganizowały jedynie w formie szczątkowej.

Opracowanie dotyczy funkcjonowania duszpasterstwa wojskowego, policyjnego i więziennego na Ukrainie. Przeprowadzona została analiza unormowań prawnych i praktyki w tym zakresie. Celem badań było wskazanie możliwych rozwiązań legislacyjnych, polegających np. na wydaniu przepisów państwowych gwarantujących opiekę religijną w formie duszpasterstw specjalnych. Stąd na końcu artykułu sformułowane zostały stosowne wnioski i postulaty.

Słowa klucze: kapelan; duszpasterstwo specjalne; wolność religijna; duszpasterstwo wojskowe; ukraiński system prawny; wolność sumienia i religii; relacje państwo-kościół

\section{$* * * * *$}

* Dr hab. prof. UO, Zakład Prawa i Postępowania Administracyjnego, Wydział Prawa i Administracji, Uniwersytet Opolski, ul. Katowicka 87a, 45-060 Opole, e-mail: jerzy-nikolajew@wp.pl, ORCID 0000-0003-1505-9710. 


\section{WPROWADZENIE}

W ustawodawstwie ukraińskim formalnie stworzono możliwość funkcjonowania duszpasterstw specjalnych dla wojska, policji i służb penitencjarnych. W ten sposób zagwarantowano realizację uprawnień z zakresu wolności sumienia i religii osobom znajdującym się w specyficznych dla siebie warunkach związanych z charakterem służby (wojskowej, milicyjnej lub więziennej), bądź pozostającym w przymusowej sytuacji (dotyczącej statusu skazanych) ${ }^{1}$. Ze względu na stosunkowo liczną populację wśród społeczeństwa ukraińskiego osób zawodowo związanych z armią (żołnierzy i wojskowych pracowników cywilnych) problematyka dotycząca właściwego uregulowania kwestii duszpasterstwa wojskowego z punktu widzenia uwzględnienia interesów państwa wydaje się być podstawową. Brakuje jednak spójnej (tzn. pochodzącej ze strony władzy i organizacji religijnych) koncepcji w przedmiotowej sprawie, co zostało uwidocznione, np. w projekcie ustawy dotyczącej kapelanów wojskowych przesłanym 23 października 2013 r. do parlamentarnej Komisji do Spraw Kultury i Duchowości. Deputowani tej Komisji nie osiągnęli porozumienia w kwestiach dotyczących sprzeczności projektu tej ustawy z art. 5 ustawy o wolności sumienia i organizacjach religijnych (chodziło o zasadę rozdziału państwa od kościoła), odpłatności za posługi religijne ze środków Ministerstwa Obrony Ukrainy, a nadto zupełnie pominięto akceptację dla tego przepisu wyrażoną przez Wszechukraińską Radę Kościołów i argumentację tam wyrażoną ${ }^{2}$ Trzeba przy tym uwzględnić fakt, że propozycje legislacyjne przedstawione $\mathrm{w}$ tym projekcie, odnoszące się do konieczności zmian różnych uregulowań ustawowych, sprowadzały się do przyjęcia następującego niemal identycznego sformułowania: „Każdy (żołnierz, żołnierz służby wewnętrznej, żołnierz służby granicznej) ma prawo do wyznawania własnej religii lub niewyznawania żadnej, praktykowania religijnego indywidualnie lub zbiorowo zgodnie z obowiązującym ustawodawstwem religijnym". Propozycja odnosiła się także do objęcia duszpasterstwem specjalnym realizowanym przez zarejestrowane organizacje religijne, także członków ich rodzin, ale generalnie na zasadzie wolontariatu. Odpłat-

Zob. Kornelûk [Корнелюк] 1998, 268.

2 www.risu.org.ua/ua/index/all_news/state/church_state_relations [dostęp: 13.11.2017]. 
ność posług religijnych uzależniono od możliwości finansowych państwa (najczęściej ograniczonych) a samych dowódców wojskowych zobowiązano do „sprzyjania”(?!) obecności duszpasterstwa w jednostkach. Przyjęcie tej propozycji legislacyjnej wymagałoby według autora projektu zmiany kilku ustaw. Chodzi tu, np. o art. 5 ustawy o wolności sumienia i organizacjach religijnych ${ }^{3}$, art. 17 ustawy o siłach zbrojnych Ukrainy ${ }^{4}$, art. 6 ustawy o ochronie socjalnej i prawnej żołnierzy zawodowych i członków ich rodzin ${ }^{5}$, art. 3 ustawy o obowiązku wojskowym i służbie wojskowej ${ }^{6}$, art. 13 ustawy o wojskach wewnętrznych podległych Ministerstwu Spraw Wewnętrznych ${ }^{7}$, art. 8 ustawy o uczestnictwie Ukrainy w międzynarodowych operacjach zapewniających pokój i bezpieczeństwo ${ }^{8}$, art. 14 ustawy o porządku w służbie wojskowej w siłach zbrojnych Ukrainy ${ }^{9}$, art. 25 ustawy o Służbie Granicznej Ukrainy ${ }^{10}$.

Celem niniejszego opracowania jest zwrócenie uwagi na niedoskonałość rozwiązań prawnych i praktyki organów państwowych Ukrainy w kwestii uregulowania kwestii związanych $\mathrm{z}$ organizacją $\mathrm{i}$ funkcjonowaniem duszpasterstw specjalnych. Obok braku odpowiednich regulacji normatywnych brakuje także opracowań naukowych z tego zakresu. Generalnie powyższa problematyka była dotąd słabo penetrowana badawczo w Ukrainie i poza nią, stąd brakuje przedmiotowej literatury a większość dostępnej została wykorzystana w niniejszym opracowaniu. Wobec występowania takich braków zmieniającą się rzeczywistość można łatwo zaobserwować $\mathrm{w}$ doniesieniach agencji religijnych zwłaszcza RISU ${ }^{11}$ i IRS ${ }^{12}$, dlatego też autor często zmuszony był szukać wsparcia swoich tez w oficjalnych przekazach pochodzących z tych agencji, które dostępne są w wersji internetowej.

\footnotetext{
Vìdomostì Verchovnoï Radi Ukraïni (dalej: VVRU) z 1991 r. Nr 25, poz. 283.

4 VVRU z 1992 r. Nr 9, poz. 108.

5 VVRU z 1992 r. Nr 15, poz. 190.

6 VVRU z 1992 r. Nr 27, poz. 385.

VVRU z 1992 r. Nr 29, poz. 397.

$8 \quad$ VVRU z 1999 r. Nr 22-23, poz. 202.

9 VVRU z 2002 r. Nr 32, poz. 225.

10 VVRU z 2003 r. Nr 27, poz. 208.

11 Релігійно-інформаційна служба України, https://risu.org.ua/

12 Інститут релігійної свободи, http://www.irs.in.ua/.
} 
Całość opracowania, które ze względów wyżej przedstawionych posiada także w dużej mierze charakter opisowy, dotyczy kolejno funkcjonowania duszpasterstw: wojskowego, milicyjnego i więziennego. Na końcu autor formułuje wnioski i postulaty, które mogą okazać się pomocne w unormowaniu relacji państwo-kościół oraz relacji pomiędzy organizacjami religijnymi.

\section{STATUS KAPELANÓW WOJSKOWYCH}

Trzeba na wstępie zaznaczyć, że formalne podstawy wprowadzenia instytucji kapelana wojskowego zostały przyjęte już na podstawie rozporządzenia Ministra Obrony Narodowej Ukrainy z 17 marca 2009 r. o utworzeniu Rady do spraw opieki duszpasterskiej przy Ministerstwie Obrony Narodowej Ukrainy jako organu doradczego i konsultacyjnego ${ }^{13}$. Na podstawie tego aktu prawnego w dniu 18 kwietnia 2009 r. ten sam organ wydał uchwałę precyzującą dość szczegółowo cele funkcjonowania Rady i jej zadania. Już na początku uchwały znalazło się sformułowanie, że Rada została powołana do koordynacji działań zapewniających wykonanie przepisów konstytucyjnych i ustawy o wolności sumienia i religii w siłach zbrojnych. Poza tym celem działania tego organu powinna być także realizacja praktycznych działań na rzecz stopniowego wprowadzania opieki religijnej i kapelanów do struktur wojskowych, współpraca międzywyznaniowa i tworzenie mechanizmów współpracy armii i organizacji religijnych w zakresie zaspokojenia potrzeb religijnych, duchowych oraz patriotycznego wychowania kadry zawodowej wojska, pracowników cywilnych i członków ich rodzin. Osobne cele funkcjonowania tej Rady związano z uczestnictwem w dyskusji nad projektami aktów prawnych dotyczących zagadnień opieki religijnej w wojsku, realizacją zadań o charakterze charytatywnym oraz z podniesieniem moralnej i psychologicznej gotowości żołnierzy do obrony ojczyzny ${ }^{14}$. Do pierwszorzędnych zadań Rady zaliczono przygotowanie dla potrzeb ministerstwa propozycji rozwiązań doty-

13 www.mil.gov.ua/index.php?part=council_pastoral_care\&sub=polozhenia [dostęp: 2.11.2017].

14 Zob. Kohančuk [Коханчук] 2011, 298. 
czących realizacji wolności religijnej członków sił zbrojnych Ukrainy oraz uczestnictwo w dyskusji nad prawnymi rozwiązaniami tych właśnie treści. Ponadto zadaniem członków Rady uczyniono dbałość o promocję współpracy międzywyznaniowej w wojsku, a zwłaszcza ,unikanie prozelityzmu i konfliktów religijnych”. W uchwale znalazły się także raczej patetyczne sformułowania związane $\mathrm{z}$,konsolidacją wysiłków związków wyznaniowych w dziedzinie duchowego i patriotycznego wychowania obrońców Ojczyzny”, wspieraniem „narodowego i kulturalnego rozwoju sił zbrojnych Ukrainy”, wspieraniem ,,wszechstronnego naświetlenia życia religijnego w siłach zbrojnych Ukrainy". W tekście uchwały umieszczono także rozwiązania praktyczne, zupełnie pozbawione patosu. Chodziło tu na przykład o propozycje Rady składane ministerstwu, co do obsady duchownych w siłach zbrojnych w czasie pokoju i kryzysu lub organizowanie szkoleń dotyczących opieki religijnej dla żołnierzy i członków ich rodzin ${ }^{15}$. Jednak pierwsze działania decydujące o kształcie kapelaństwa wojskowego związane były ze spotkaniem, do którego doszło 11 lutego 2010 r. z udziałem przedstawicieli MON i Rady społecznej do spraw opieki religijnej działającej przy tym resorcie. Wówczas nakreślono wstępny zarys koncepcji opieki religijnej na rzecz żołnierzy, pracowników cywilnych ukraińskiej armii oraz członków ich rodzin. Przewodniczący Rady abp Augustyn Markiewicz (Patriarchat Moskiewski) zwrócił wówczas uwagę na doświadczenia duchownych ukraińskich, którzy razem z żołnierzami uczestniczyli w misjach pokojowych w Iraku i Bośni. Z kolei ks. Lubomir Jaworskij (Kościół Greckokatolicki) podkreślił możliwość skorzystania z rozwiązań obowiązujących w innych państwach, w których duszpasterstwo wojskowe wpisało się już na trwałe ${ }^{16}$.

Potrzebę konsekwentnego działania na rzecz utworzenia duszpasterstwa w wojsku wyrażono także podczas dorocznego spotkania kapelanów wojskowych zorganizowanego w Czernichowie w dniach 29-30 października 2013 r. przez cerkiew moskiewskiego patriarchatu ${ }^{17}$. Poza tym w Mi-

15 www.mil.gov.ua/index.php?part=council_pastoral_care\&sub=memorandum [dostęp:

\subsubsection{7 r.].}

16 Zob. także Kovalenko 2002, 28.

17 Problemy duszpasterstwa wojskowego zdominowane zostały jednak przez informacje o zakończonych właśnie wtedy obchodach 1025. rocznicy chrztu Rusi Kijowskiej. Spotkaniu z udziałem 49 duchownych pochodzących z 36 diecezji przewodniczył bp Augustyn 
nisterstwie Obrony Ukrainy wciąż funkcjonuje kolegialne ciało w postaci Rady do spraw duszpasterstwa wojskowego, będącej naturalnym sprzymierzeńcem działań legislacyjnych na rzecz najpierw wprowadzenia, a potem wykonania ustawy dopuszczającej możliwość sprawowania opieki religijnej w wojsku ${ }^{18}$.

Poza tym o pilne uregulowanie wszystkich kwestii prawnych i organizacyjnych dotyczących duszpasterstwa w armii ukraińskiej zaapelował 20 czerwca 2014 r. bp Mychajło Kołtun z Ukraińskiego Kościoła Greckokatolickiego w kontekście militarnego zagrożenia integralności Ukrainy i w związku z wydarzeniami na Krymie. Przewodniczący Wydziału Duszpasterstwa Wojskowego Kościoła Greckokatolickiego wezwał wszystkich 57 kapelanów wojskowych swojego kościoła do stawienia się do jednostek wojskowych, gdyż ,jest to czas wysokiej aktywności duchowej w wojsku" ${ }^{\prime 19}$. Ten sam hierarcha potwierdził także obecność duchownych tego Kościoła posługujących wśród żołnierzy ukraińskich broniących integralności państwa w obwodzie donieckim i ługańskim. Bp M. Kołtun przypomniał, że oprócz greckokatolickich kapelanów wojskowych na wschodzie kraju obecni są także duchowni Kościołów protestanckich ${ }^{20}$. Jego zastępca, ks. Lubomir Jaworskij, po powrocie ze wschodu Ukrainy, gdzie obserwował zaangażowanie duszpasterskie duchownych różnych konfesji, potwierdził konieczność ich obecności wśród ukraińskich żołnierzy walczących z miejscowymi separatystami. Zauważył też wtedy, że wciąż brakuje przepisów umożliwiających instytucjonalną obecność duchownych w strukturach wojskowych Ukrainy, co wobec zagrożenia integralności

Markiewicz, będący z ramienia Cerkwi moskiewskiej przewodniczącym Departamentu do spraw opieki duszpasterskiej w tzw. siłowych resortach Ukrainy, www.risu.org.ua/ua/index/ all_news/community/faith_and_weapon/54152 [dostęp: 3.11.2017].

18 Od 9 grudnia 2013 r. przewodniczącym Rady jest Mykoła Andraszko, wiceprzewodniczący Związku Chrześcijan Baptystów, który zastąpił na tym stanowisku biskupa Stanisława Szyrokoradiuka z rzymskokatolickiej diecezji kijowsko-żytomierskiej, www.irs. in.ua/index.php?option $=$ com_content $\&$ view $=$ article $\&$ id $=1312: 1 \&$ catid $=34:$ ua\&Itemid $=61$ \&lang=uk [dostęp: 3.11.2017].

19 www.risu.org.ua/ua/index/all_news/community/faith_and_weapon/55595 [dostęp: 6.11.2017].

20 www.risu.org.ua/ua/index/all_news/state/national_religious_questions/56804 [dostęp: 2.11.2017]. 
państwa wydaje się być poważnym niebezpieczeństwem. Ponadto podkreślił konieczność przeprowadzenia szkolenia dla kapelanów wojskowych (przynajmniej dla tych, którzy nie mieli wcześniej żadnego kontaktu z armią), chociaż z drugiej strony wskazał na fundamentalne znaczenie samej obecności duchownych wśród żołnierzy ${ }^{21}$. Ten sam duchowny uczestniczył 1 października 2014 r. w posiedzeniu Rady do spraw duszpasterstwa wojskowego przy Ministrze Obrony Narodowej Ukrainy zwołanej z inicjatywy Sztabu Generalnego Sił Zbrojnych Ukrainy poświęconej w całości problematyce obecności kapelanów wojskowych w strefie ATO. W spotkaniu Rady wzięli udział także wysocy oficerowie ukraińskiego Sztabu Wojskowego oraz Maksim Wasin - dyrektor wykonawczy Instytutu Wolności Religijnej, Jurij Reszetnikow - przewodniczący Państwowego Komitetu Ukrainy do spraw Narodowości i Religii a także duchowni greckokatoliccy. Reprezentujący stronę kościelną ks. Aleksandr Miler odniósł się także do potrzeb etatowych niezbędnych dla prawidłowego funkcjonowania kapelaństwa wojskowego (8 etatów). Z kolei przedstawiciel wojska (konkretnie ministerstwa) płk Rusłan Kochanczuk aktualne możliwości resortu obrony narodowej określił na poziomie 4 etatów kapelańskich. Natomiast wszyscy uczestnicy posiedzenia zgodni byli, co do konieczności zwiększenia obsady etatowej i znaczenia obecności osób duchownych w sytuacji prowadzonych działań wojennych ${ }^{22}$. Ks. Lubomir Jaworskij w wywiadzie udzielonym 15 grudnia 2014 r. tygodnikowi „Zerkało Tydnia” krytycznie odniósł się do posługi kapelańskiej duchownych Ukraińskiego Kościoła Prawosławnego Patriarchatu Moskiewskiego. Wskazał tu na przypadek odmowy pogrzebu „wyznaniowego” w stosunku do żołnierza ukraińskiego zabitego w strefie ATO, gdyż „walczył on przeciw rosyjskim braciom”. Żona zmarłego złożyła w tej sprawie skargę do Ministerstwa Obrony, ponieważ duchowny odmawiający pogrzebu był etatowym kapelanem zatrudnionym $\mathrm{w}$ duszpasterstwie wojskowym ${ }^{23}$. W tym samym czasie, bo

21 www.risu.org.ua/ua/index/all_news/community/faith_and_weapon/56843 [dostęp: 4.11.2017].

22 www.risu.org.ua/ua/index/all_news/community/faith_and_weapon/57834 [dostęp: 11.11.2017].

23 www.religion.in.ua/news/ukrainian_news/27857-voennyj-kapella-ugkc-v-kieve-k-relichajshemu-sozhalehiyu-vse-bolshe-i-bolshe-iz-voennogo-gospitalya-postupaet-zhalob-na-svyashhennosluzhitelej-moskovskogo-patriarxata.html [dostęp: 4.11.2017]. 
23 grudnia 2014 r. na jednym z portali internetowych opublikowano informację, że metropolita mikołajowski i oczakowski Pitrim Starinskij z Ukraińskiego Kościoła Prawosławnego Patriarchatu Moskiewskiego zabronił duchownym swojej diecezji udzielania jakiegokolwiek wsparcia wojsku ukraińskiemu walczącemu w rejonie operacji antyterrorystycznych, co wywołało oburzenie internautów i obraźliwe komentarze na ten temat ${ }^{24}$. Do podobnego zdarzenia doszło także $\mathrm{z}$ udziałem biskupa czerniowieckiego Longinusa (pochodzącego z tego samego Kościoła), który na łamach rumuńskojęzycznej gazety „Libertatea Cuvantului” (z 22 stycznia 2015 r.), wychodzącej także na ukraińskiej Bukowinie, wezwał swoich wiernych do oportunizmu wobec mobilizacji do wojska. Hierarcha apelował o to, żeby „nie podejmować walki z Rosjanami i nie przelewać prawosławnej krwi” a za wywołanie konfliktu rosyjsko-ukraińskiego obwinił Stany Zjednoczone będące „sługą szatana”. Władze w Kijowie zaprotestowały przeciwko tej wypowiedzi i potraktowały ją jako ,zakłócanie mobilizacji wojska na tych terenach" 25 . Natomiast dziennikarze obecni na dorocznej konferencji dziennikarzy obwodu czerniowieckiego 1 lutego 2015 r. przegłosowali prawie jednomyślnie wniosek o pozbawienie bpa Longinusa „Tytułu Bohatera Ukrainy" w związku z jego wypowiedzią z 22 stycznia. Złożyli tej sprawie formalny wniosek i wysłali go do prezydenckiej kancelarii ${ }^{26}$. Przedstawiciele Ministerstwa Kultury i Ministerstwa Spraw Wewnętrznych na specjalnie zwołanej konferencji prasowej ujawnili inny, podobny przypadek związany z apelem o niepodejmowanie akcji mobilizacyjnej, tym razem pochodzący ze strony przełożonego cerkwi Dziesięcinnej w Kijowie. Obydwie te sprawy zostały zgłoszone do prokuratury z wnioskiem o ściganie sprawców ${ }^{27}$.

Już po wprowadzeniu w życie przepisów państwowych dotyczących duszpasterstwa wojskowego abp Augustyn, przewodniczący synodu biskupów Ukraińskiego Kościoła Prawosławnego Patriarchatu Moskiewskiego

24 www.risu.org.ua/ua/index/all_news/community/religion_and_policy/58588 [dostęp: 5.11.2017].

25 www.risu.org.ua/ua/index/all_news/state/national_religious_questions/58911 [dostęp: 7.11. 2017].

26 www.risu.org.ua/ua/index/all_news/orthodox/uoc/58968 [dostęp: 2.11.2017].

27 www.risu.org.ua/ua/index/all_news/state/church_state_relations/58950 [dostęp: 9.11. 2017]. 
do spraw współpracy z wojskiem i resortami siłowymi, zatwierdził decyzję synodalną o wprowadzeniu duchownych tego Kościoła do sił zbrojnych Ukrainy. Jednocześnie postanowiono, że każdego roku w niedzielę po uroczystości Podwyższenia Krzyża obchodzone będzie liturgiczne wspomnienie zmarłych i poległych żołnierzy ukraińskich ${ }^{28}$. Także w Kościele baptystycznym doszło do spotkania (4 listopada 2015 r.) w Kijowie grupy kapelanów wojskowych tej wspólnoty religijnej z przedstawicielami resortu obrony na temat zasad współpracy państwowo-kościelnej w zakresie duszpasterstwa w armii ukraińskiej. Ze strony kościelnej uczestniczył zwierzchnik kościoła na Ukrainie bp Mychajło Panoczko i odpowiedzialny za kapelanów wojskowych pastor Wiaczesław Kogut a stronę ministerialną reprezentował płk R. Kochanczuk ${ }^{29}$.

Również metropolita lwowski Ukraińskiego Kościoła Greckokatolickiego abp Ihor Woźniak na stronie internetowej cerkwi wsparł ukraińskich żołnierzy walczących na wschodzie Ukrainy. W liście z 6 lipca 2014 r. napisał o nich, że „są nową generacją bohaterów narodowych i dzielnymi obrońcami naszego narodu. Metropolita zauważył też, że „wydarzenia te pokazują dobitnie, że Ukraina wstała z kolan i nie pozwoli zakuć się w kajdany" "30. Zresztą Kościół Greckokatolicki na Ukrainie od początku wykazywał spore zainteresowanie utworzeniem struktur duszpasterstwa wojskowego. Podczas każdego z dorocznych zjazdów kapelanów tego Kościoła podnoszono kwestię ustawy o kapelaństwie wojskowym ${ }^{31}$. Na przykład, w trakcie VIII Krajowego Zjazdu Kapelanów Wojskowych Ukraińskiego Kościoła Greckokatolickiego w dniach 23-25 grudnia 2014 r. w Kijowie (ok. 50 uczestników) dyskutowano o konieczności pilnego zakończenia prac legislacyjnych wokół ustawy „kapelańskiej”, jak też o opie-

\subsubsection{7].}

28 www.risu.org.ua/ua/index/all_news/orthodox/uoc/61524 [dostęp: 9.11.2017].

29 www.risu.org.ua/ua/index/all_news/community/faith_and_weapon/61665 [dostęp:

30 www.risu.org.ua/ua/index/all_news/community/catholics/ugcc/56997 [dostęp: 9.11. 2017].

31 Także duchowni rzymskokatoliccy i greckokatoliccy z Ukrainy uczestniczyli w 57. pielgrzymce kapelanów wojskowych pochodzących z krajów byłej Jugosławii (12-19 lipca 2015 r.) do sanktuarium we francuskim Lourdes. Kilkuosobowa grupa kapelanów z Ukrainy została zaproszona przez Chorwatów po raz pierwszy. Zob. „Lurd: 57.vojno hodosace", Nasa ognijista 2015, nr 8, s. 17. 
ce duszpasterskiej nad żołnierzami ukraińskimi walczącymi w strefie ATO. Zjazd kapelański zorganizował wspominany wielokrotnie ks. Lubomir Jaworskij, zastępca dyrektora departamentu kurii patriarszej do spraw duszpasterstwa wojskowego, a uczestniczył w nim bp Bohdan Dziurakh, administrator kurii patriarchalnej w Kijowie ${ }^{32}$. Poza tym 22 stycznia 2015 r. metropolita lwowski Ihor Woźniak zezwolił wolontariuszom z organizacji pozarządowej „Idź i Zwyciężaj” na zbiórkę pieniędzy przez „kolędników” odwiedzających lwowskie rodziny i przekazanie ich na rzecz ukraińskiej armii. Wstępnie obliczono, że możliwe było uzyskanie nawet kwoty rzędu 2,5 mln dolarów przyjmując ofiarność miejscowych grekokatolików i ich rodzin (250 tys.) na poziomie 10 dolarów miesięcznie. Ośrodkiem koordynacji tych działań uczyniono parafię garnizonową św. Piotra i Pawła we Lwowie, a z zebranych funduszy zakupiono ciepłą odzież dla ukraińskich żołnierzy walczących w Donbasie ${ }^{33}$.

Ostatecznie, jeszcze 25 listopada 2014 r. synod Ukraińskiego Kościoła Greckokatolickiego podjął uchwałę o powołaniu kościelnej Rady do spraw koordynacji duszpasterstwa w sytuacjach kryzysowych, a kierowanie jej pracami powierzył biskupowi pomocniczemu ze Stryja Bohdanowi Manyszynowi ${ }^{34}$. Podstawowe cele działania Rady to koordynowanie różnych działań pomocowych na rzecz żołnierzy ukraińskich walczących w strefie ATO i wysiedlonych stamtąd osób cywilnych. Biskupi greckokatoliccy uznali, że dotychczasowa pomoc miała charakter doraźny a sytuacja wielu osób na wschodzie wymaga profesjonalnie zorganizowanej i efektywnej pomocy ${ }^{35}$.

W tym samym czasie ukraiński rząd podjął zdecydowane działania legislacyjne związane z przygotowaniem przepisów umożliwiających pełnienie przez kapelanów wojskowych służby w pełnym wymiarze czasu pracy. Zgodnie z rozporządzeniem Gabinetu Ministrów Ukrainy (nr 677-r) z 2 lipca 2014 r. zobowiązano kierownictwo resortów obrony narodowej, spraw wewnętrznych i Administracji Służby Granicznej Ukrainy do

\footnotetext{
6.11.2017].

33 www.risu.org.ua/ua/index/all_news/community/faith_and_weapon/588873 [dostęp: 3.11.2017].

34 Zob. także Kozyrska 2014, 45.

35 www.risu.org.ua/ua/index/all_news/catholics/ugcc/59323 [dostęp: 6.11.2017].
}

32 www.risu.org.ua/ua/index/all_news/community/faith_and_weapon/58608 [dostęp: 
przygotowania odpowiednich przepisów w terminie do 1 sierpnia $2014 \mathrm{r}$. Chodziło głównie o wprowadzenie zmian w obowiązujących klasyfikatorach stanowisk służbowych (wprowadzenie nowego stanowiska kapelana) i podjęcie szkoleń specjalistycznych dla kapelanów ${ }^{36}$. Także 29 sierpnia 2014 r. Rada społeczna przy Ministerstwie Obrony Narodowej pozytywnie zaopiniowała projekt rozporządzenia w tej sprawie i wskazała na potrzeby etatowe związane $\mathrm{z}$ uruchomieniem duszpasterstwa wojskowego (łącznie ok. 180 etatów). Wszyscy uczestnicy spotkania (przewodniczący Rady Jurij Reszetnikow, doradca premiera Wiktor Jelenskij, prezes Instytutu na Rzecz Wolności Religijnej Maksim Wasin, przedstawiciele patriarchatu kijowskiego, patriarchatu moskiewskiego, Kościoła Greckokatolickiego, Rzymskokatolickiego i Baptystycznego) jednomyślnie opowiedzieli się za wprowadzeniem w życie nowych przepisów ${ }^{37}$. Ostatecznie 27 stycznia 2015 r. minister obrony narodowej Ukrainy płk Stepan Połtorak podpisał rozkaz ( $\mathrm{nr} 40$ ) o zatwierdzeniu położenia kapelanatu wojskowego i tego samego dnia przekazał go do Ministerstwa Sprawiedliwości w celu zarejestrowania tego aktu prawnego, będącego naturalną konsekwencją realizacji postanowień rozporządzenia Gabinetu Ministrów z 2 lipca 2014 r. Minister obrony miał 6 miesięcy na uzgodnienie ostatecznej wersji przepisów kapelańskich z innymi instytucjami i organami państwowymi. Nowe przepisy objęły funkcjonowanie duszpasterstwa specjalnego w wojsku, Gwardii Narodowej i Straży Granicznej, ale poza tymi regulacjami znalazły się takie formacje mundurowe, jak milicja i więziennictwo, pozostające formalnie poza resortem obrony. Stąd też według przepisów duszpasterskich MON z 27 stycznia 2015 r. podstawowym zadaniem duszpasterstwa wojskowego uczyniono ,opiekę duchową nad żołnierzami i członkami ich rodzin poprzez przybliżanie im pozytywnych cech charakteru i wartości moralnych". W tym samym przepisie określono także wymogi formalne dla kandydatów do pełnienia posługi kapelańskiej w wojsku. Pierwszy warunek dotyczył wymogu trzyletniego stażu kapłańskiego lub równoważnego na stanowisku duchownego. Wymagano też posiadania misji kanonicz-

36 www.risu.org.ua/index/all_news/community/faith_and_weapon/57201 [dostęp: 11.11. 2017].

37 www.risu.org.ua.index/all_news/state/church_state_relations/57524 [dostęp: 2.11 . 2017]. 
nej pochodzącej od władzy zwierzchniej wspólnoty religijnej, z tym że wyeliminowane zostały już na wstępie te kościoły i organizacje religijne, które nie należały wcześniej do Rady duszpasterstwa wojskowego przy Ministerstwie Obrony Narodowej ${ }^{38}$. Kolejny wymóg powiązano z koniecznością uprzedniego przeszkolenia wojskowego i formalnej akceptacji dla regulaminów obowiązujących w wojsku. Poza tym na kandydatów na kapelanów wojskowych nałożono obowiązek posiadania obywatelstwa ukraińskiego i znajomości tego języka. Powyższe wymogi uzgodnione zostały wcześniej z Radą Kościołów (VRCiRO), bo pierwsze porozumienie w sprawie duszpasterstwa wojskowego zostało podpisane z resortem obrony narodowej już 10 listopada 2008 r. w zupełnie innych realiach prawnych i faktycznych ${ }^{39}$.

Także 8 lipca 2015 r. Synod Biskupów Ukraińskiego Kościoła Prawosławnego Patriarchatu Kijowskiego, opierając się na nowych przepisach, zdecydował o wprowadzeniu dość radykalnych rozwiązań w zakresie faktycznego pełnienia posługi kapelańskiej w wojsku. Biskupi podjęli uchwałę na podstawie której zobowiązano wszystkich duchownych tego Kościoła w wieku pomiędzy 25 a 55 rokiem życia do zgłoszenia w terminie do 17 lipca 2015 r. swojej gotowości sprawowania takiej właśnie funkcji w armii ukraińskiej. Koordynacją tych działań miał się zająć synodalny wydział do spraw kapelaństwa wojskowego, a odpowiedzialnością za wykonanie uchwały obarczyli się sami biskupi. Przyjęto czteromiesięczny „klucz”, według którego duchowni mieli pełnić służbę w wojsku przez miesiąc, a trzy kolejne poświęcić na pracę na rzecz parafii. Zwolnienia miały dotyczyć wyjątkowo osób chorych ${ }^{40}$. Podobnie zdecydowane działania na rzecz zwiększenia liczby kapelanów wojskowych w strefie ATO podjął metropolita czerkaski Joan (patriarchat kijowski), który 24 września 2015 r. spotkał się z dyrektorem Departamentu Służby Granicznej Ukrainy gen. Nikołajem Nesterenko. Podczas spotkania ustalono wstępne warunki udziału kapelanów Służby Granicznej w posłudze duszpasterskiej razem z kapelanami wojsko-

38 Zob. Vladičenko [Владиченко] 2013, 56.

39 www.risu.org.ua/ua/index/all_news/community/faith_and_weapon/59003 [dostęp:

4.11.2017]. Zob. także rozważania na ten temat S'Omin [Сьомін] 2000, 99-104.

40 www.risu.org.ua/ua/index/all_news/community/faith_and_weapon/60488 [dostęp: 9.11.2017]. 
wymi w Donbasie ${ }^{41}$. Poza tym patriarchat kijowski zobowiązał wszystkich kapelanów wojskowych swojego Kościoła, by przed rozpoczęciem posługi w strefie ATO przedstawili stosowne skierowanie z Synodu kościoła oraz dokumenty ze Sztabu Generalnego Sił Zbrojnych Ukrainy. Przyjęto też do stosowania praktykę 30-dniowych kontyngentów i wyposażania kapelanów przez stronę kościelną w odpowiedni ekwipunek osobisty w postaci kurtki wojskowej, butów, pasa taktycznego i logo służby kapelańskiej ${ }^{42}$.

\section{STATUS KAPELANÓW MILICYJNYCH/POLICYJNYCH ${ }^{43}$}

Równolegle do działań prowadzonych w siłach zbrojnych przygotowano dokument w sprawie projektu przepisów dotyczących usankcjonowania duszpasterstwa milicyjnego. Wszechukraińska Rada Kościołów i Organizacji Religijnych przesłała 26 listopada 2013 r. swoją propozycję w tej sprawie, ale nie do Rady Najwyższej, lecz do ówczesnego prezydenta Janukowicza i odpowiedzialnego wtedy za milicję ministra spraw wewnętrznych Witalija Zakharenko. Była to forma protestu ukraińskich kościołów zrzeszonych w Radzie Kościołów ze względu na „fakt rażącego bezprawia i samowoli ze strony niektórych organów ścigania Ukrainy" oraz „próba podjęcia środków zmierzających do reformy milicji, zwłaszcza w obszarze moralnych i duchowych potrzeb". Kategoryczny ton tej wypowiedzi był zapewne usprawiedliwiony medialnymi doniesieniami o zdarzeniu w miejscowości Wradiwica (województwo mikołajowskie). Milicjanci zgwałcili tam przesłuchiwaną kobietę, a ich przełożeni pomogli w zatarciu śladów przestępstwa ${ }^{44}$. Duchowni obecni na uroczystościach państwowych z udziałem milicji tradycyjnie apelują do nich o zachowanie ludzkich i ewangelicznych standardów w służbowym działaniu. Krytycznie do przypadku z Wradiwicy odniósł się także abp Augustyn

41 www.risu.org.ua/ua/index/all_news/community/faith_and_weapon/61241 [dostęp: 10.11.2017].

42 www.risu.org.ua/ua/index/all_news/community/faith_and_weapon/61293 [dostęp: 10.11.2017].

$43 \mathrm{Z}$ dniem 1 lipca 2015 r. wprowadzono zmiany w nazewnictwie tej formacji.

44 www.irs.in.ua/index.php?option=com_content\&view=article\&id=1305: 17 catid=34 :ua\&Itemid=61lang=ua [dostęp: 3.11.2017]. 
Markiewicz ${ }^{45}$ (Ukraiński Kościół Prawosławny Patriarchatu Moskiewskiego), przewodniczący synodalnego wydziału do spraw kontaktów z siłami zbrojnymi Ukrainy, podczas dorocznego Święta Milicji obchodzonego 20 grudnia 2013 r. Słowa potępienia zostały wypowiedziane wobec przełożonych milicjantów i prezydenta Ukrainy w trakcie nabożeństwa w kijowskim Soborze Bohosławskim ${ }^{46}$. Niezależnie od tego duchowni sprawujący faktycznie (bez wprowadzenia ustawy) posługę na rzecz środowiska milicyjnego podejmują działania integrujące ich zawodowo, np. poprzez odprawianie uroczystych panachid, organizowanych z okazji przypadającego co roku w dniu 22 sierpnia Dnia Pamięci Ukraińskich Milicjantów, którzy zginęli na służbie ${ }^{47}$.

\section{STATUS KAPELANÓW WIĘZIENNYCH}

Podobne inicjatywy dotyczą też duszpasterstwa więziennego. Pierwsze tego typu działania były wspólne dla wojska i więziennictwa, gdyż

45 Abp Augustyn, występując jako naczelny kapelan sił zbrojnych Ukrainy, 4 marca 2014 r. udzielił błogosławieństwa żołnierzom ukraińskim broniącym integralności granic państwa ukraińskiego w kontekście zagrożenia militarnego ze strony Federacji Rosyjskiej na półwyspie krymskim. www.risu.org.ua/ua/index/all_news/state/national_religious_questions/55569 [dostęp: 4.02.2018]. Także z inicjatywy abpa Augustyna Markiewicza 30 kwietnia 2014 r. Wydział synodalny do spraw współpracy z siłami zbrojnymi Ukraińskiego Kościoła Prawosławnego Patriarchatu Moskiewskiego wezwał obywateli Ukrainy do podjęcia zbiórki funduszy na rzecz materialnego wsparcia ukraińskiej armii, www.religion. in.ua/news/vazhlivo/25683-na-proge-vojny-ukrainy-s-rossiej-upc-nachala-sbor-sredstv-na-podderzhku-ukrainskoj-armi.html [dostęp: 5.11.2017].

46 www.risu.org.ua/ua/index/all_news/state/national_religious_question/54704 [dostęp: 3.11.2017].

47 W 2013 r. uroczystościom religijnym w cerkwi św. Michała Archanioła (patrona milicjantów) przewodniczył metropolita kijowski i browarski Teodozjusz z patriarchatu moskiewskiego. Uczestniczył także szef kijowskich policjantów generał wewnętrznej służby Walerij Korjak i rodziny funkcjonariuszy poległych na służbie. Według szacunków milicji od 1991 r., czyli od uzyskania przez Ukrainę niepodległości, na służbie zginęło 307 milicjantów, z czego 38 w Kijowie, dlatego też w tym mieście każdego roku w dniu 22 sierpnia milicjanci z posterunków w Kijowie zapalają znicze i chwilą ciszy upamiętniają nieżyjących już kolegów, www.risu.org.ua/ua/all_news/community/religion_and_society/53451 [dostęp: 3.11.2017]. 
grupa robocza powstała w 2012 r. w biurze przedstawiciela prezydenta w Radzie Najwyższej Ukrainy przygotowywała projekt ustawy o kapelaństwie w wojsku i więzieniach. Podczas drugiego spotkania tego gremium 11 lipca 2013 r. z udziałem przedstawiciela prezydenta Jurija Miroszniczenko oraz duchownych prawosławnych z Patriarchatu Kijowskiego, przedstawicieli wspólnoty żydowskiej, adwentystycznej, Chrześcijan Wiary Ewangelicznej i Ukraińskiego Kościoła Greckokatolickiego oraz Rusłana Kochanczuka, reprezentanta armii, Olega Janczuka z więziennictwa i Maksima Wasina, dyrektora IRS, postanowiono rozdzielić sferę wojskowości i więziennictwa, i odtąd realizować dwa osobne projekty ${ }^{48}$. Już 13 września 2013 r. do parlamentu przekazano projekt nr 3233 ustawy dotyczącej dopuszczenia kapelanów do więzień. Inicjatywa ustawodawcza w tym przypadku wyszła ze strony Wszechukraińskiej Rady Kościołów i Organizacji Religijnych, a także departamentu więziennictwa w Ministerstwie Sprawiedliwości Ukrainy. Projekt przewidywał utworzenie organu doradczego do spraw duszpasterstwa więziennego w Ministerstwie Sprawiedliwości, potrzebę szkolenia kapelanów więziennych z zakresu problematyki uzależnień, przygotowania skazanych do zwolnienia z zakładu karnego i pomocy postpenitencjarnej ${ }^{49}$. Niezależnie od tego wnioskodawcy zwrócili uwagę na konieczność wprowadzenia zmian do ustaw o tymczasowo aresztowanych i o służbie penitencjarnej. Projekt w ocenie J. Miroszniczenko należało traktować z należnym uznaniem i uwzględnić także fakt, że „po wojsku przyszła kolej na więziennictwo" ${ }^{50}$. Miroszniczenko był też autorem kolejnego projektu (tym razem nadano mu nr 1154), w którym zaproponował wprowadzenie do kodeksu karnego wykonawczego (art. 128-1) przepisów dotyczących duszpasterstwa więźniów, zmiany art. 9 i 12 ustawy o wykonywaniu aresztu tymczasowego i dodanie do art. 23 ustawy o administracji penitencjarnej obowiązku wspierania przez administrację penitencjarną duszpasterstwa więziennego. Projekt nr 1154 uzyskał poparcie Komisji Porządku Publicznego Rady Najwyższej

48 www.risu.org.ua/ua/index/all_news/community/faith_and_weapon/52951 [dostęp: 3.11.2017].

49 Zob. także Warzonek 2014.

50 www.risu.org.ua/ua/index/all_news/community/faith_and_weapon/53664 [dostęp: 3.11.2017]. 
Ukrainy, która 27 grudnia 2014 r. przekazała go do dalszych prac legislacyjnych $^{51}$. Ostatecznie 11 lutego 2015 r. Rada Najwyższa przyjęła projekt w kształcie zaproponowanym przez wnioskodawców. Eksperci zauważyli jednak potrzebę dostosowania tego przepisu do standardów ONZ, czyli do Reguł Minimalnych Postępowania z Więźniami i powołania międzyreligijnego organu doradczego do spraw duszpasterstwa więziennego na Ukrainie $^{52}$. Finalnie dopiero 14 maja 2015 r. udało się ,przeforsować” projekt i wówczas Rada Najwyższa uchwaliła zmiany wprowadzające duszpasterstwo więzienne do art. 23 ustawy o administracji więziennej. Uchwalenie tej ustawy to efekt szczególnego zaangażowania duchowieństwa Ukraińskiego Kościoła Greckokatolickiego w Radzie Najwyższej (w charakterze ekspertów $)^{53}$. Stąd też należało podjąć działania na rzecz praktycznej realizacji tych uprawnień i 24 września 2015 r. w Departamencie Więziennictwa w Kijowie zorganizowano naradę roboczą na temat możliwości kształcenia kapelanów więziennych w ośrodku kształcenia kadry więziennej w Białej Cerkwi (obowiązek kształcenia kapelanów przewidziano w ustawie). Ustalono wówczas, że edukacja obejmować będzie zagadnienia prawnych podstaw duszpasterstwa więziennego, wiedzy z zakresu pedagogiki i psychologii oraz specyfiki duszpasterstwa penitencjarnego. Uczestnicy spotkania, w którym poza pracownikami więziennej centrali uczestniczyli także dyrektor wykonawczy Misji Chrześcijańskiej Więziennej Wiaczesław Kogut, Wiktor Jacenko (Patriarchat Moskiewski) i ks. Konstantyn Pantelej (Kościół Greckokatolicki) przypomnieli, że idea kształcenia kapelanów w Białej Cerkwi była już wcześniej realizowana, mimo braku formalnych podstaw do takiego działania. Chodziło tu o lata 2005-2009, kiedy pod nadzorem ówczesnego szefa ukraińskiego więziennictwa Wasyla Koszczyńca i jego zastępcy dr Natalii Kałasznik zajęcia dla kapelanów więziennych różnych wyznań prowadzono w cyklu miesięcznym ${ }^{54}$.

Trzeba jednak wyraźnie podkreślić zaangażowanie w budowę struktur duszpasterstwa więziennego i realizację opieki duchowej na rzecz osób

51 www.risu.org.ua/index/all_news/community/faith_and_weapon/58669 [dostęp: 11.11. 2017].

52 www.risu.org.ua/ua/index/all_news/state/legislation/59105 [dostęp: 11.11.2017].

53 www.risu.org.ua/ua/index/all_news/state/legislation/60000 [dostęp: 3.11.2017].

54 www.religion.in.ua/news/ukrainian_news/30478-dlya-duxovenstva-ukrayini-provedut-kurs-pidgotovki-vyaznichnix-kapelaniv.html [dostęp: 3.11.2017]. 
pozbawionych wolności widoczne w działaniach przedstawicieli Ukraińskiego Kościoła Greckokatolickiego, którzy już 2 kwietnia 2007 r. podpisali w tej sprawie stosowne porozumienie z Departamentem Wykonywania Kary Pozbawienia Wolności, nadzorującym funkcjonowanie wszystkich zakładów karnych i aresztów śledczych na Ukrainie ${ }^{55}$. Wobec nowych projektów przepisów dotyczących sytuacji duszpasterskiej w wojsku i milicji 12 grudnia 2012 r. biskup sokalski Bogdan Kołtun, odpowiedzialny z ramienia Kościoła za kontakty ze strukturami zmilitaryzowanymi, podpisał nowe porozumienie, uwzględniające szerzej niż dotąd możliwości zabezpieczenia uprawnień religijnych więźniów, upowszechnienia w więzieniach zasad moralności, profilaktyki AIDS, alkoholizmu i narkomanii, przygotowania skazanych do zwolnienia, ich uczestnictwa w życiu sakramentalnym, zasad pracy duchownych i świeckich, dostarczania do więzień literatury religijnej, paczek, lekarstw i żywności ${ }^{56}$. Według władz Cerkwi greckokatolickiej na Ukrainie realizacji tych właśnie zadań miał dodatkowo sprzyjać fakt obrania za patrona greckokatolickiego duszpasterstwa więziennego osoby błogosławionego męczennika Weliczkowskija, więźnia okresu stalinowskiego ${ }^{57}$.

Pierwszą wspólnotą religijną, jaka pojawiła się w ukraińskich więzieniach po uzyskaniu niezależności państwowej był Ukraiński Kościół

55 Zob. Pantelej [Пантелей] 2012, 14.

56 www.risu.org.ua/ua/index/all-news/community/faith_and_weapon/53940 [dostęp: 3.11.2017].

57 Błogosławiony Męczennik Weliczkowskij został skazany na karę śmierci, zamienioną potem na 10 lat obozów pracy. Później wyświęcony został potajemnie na biskupa, wyjechał do Kanady, gdzie zmarł 30 czerwca 1973 r. Pochowano go w Winnipeg a ciało po ekshumacji okazało się nienaruszone. Począwszy od Niedzieli o Synu Marnotrawnym w 2014 r. obchodzi się jego wspomnienie w kaplicach więziennych. Należy jednak pamiętać, że od 2008 r. duszpasterze więzienni z tego kościoła mają już patrona w osobie bł. Emiliana Kowcza, nazywanego proboszczem Majdanka. Trzeba także przypomnieć, że od 2001 r. przyznawana jest nagroda imienia E. Kowcza tym osobom i organizacjom, które działają na rzecz dialogu ekumenicznego, międzynarodowego i pomocy charytatywnej. W 2015 r. wyróżnienie przyznano za wsparcie żołnierzy ukraińskich w strefie ATO (Międzynarodowy Fundusz Solidarności z Polski, Przyjaciele Ukrainy z Izraela, Juliana i Mark Supun z Kanady oraz ks. Bazyli Iwaniuk i Klaudia Poliszuk - oboje z Ukrainy), www.risu.org.ua/index/all_news/community/faith_and_weapon/53939 [dostęp: 3.11.2017]. 
Prawosławny Patriarchatu Kijowskiego ${ }^{58}$. Przypomniał o tym patriarcha Filaret podczas spotkania 4 kwietnia 2014 r. z nowym przewodniczącym Państwowego Departamentu Więziennictwa Serhijem Starenko. Zwierzchnik „kijowskiego prawosławia” w obecności ks. Petro Osnowenko, przewodniczącego wydziału do spraw współpracy cerkwi z osobami pozbawionymi wolności, podziękował szefowi więziennictwa za wieloletnią współpracę Służby Penitencjarnej Ukrainy z kapelanami więziennymi, a Starenko wyraził wdzięczność cerkwi za dotychczasową pomoc oraz omówiono zasady przyszłego współdziałania obydwu podmiotów ${ }^{59}$. Obecnie także wyznawcy innych religii przebywający w ukraińskich więzieniach mogą swobodnie praktykować religijnie, skoro np. 1 lutego 2012 r. (w dniu upamiętnienia urodzin proroka Mahometa) w „wyprawnoj kolonii" nr 18 w Chołodnogorsku (obwód czerkaski) otwarto pierwsze pomieszczenie modlitewne dla wyznawców islamu. W chwili otwarcia ta grupa wyznaniowa liczyła ok. 30 osób i pomieszczenie o takiej mniej więcej pojemności utworzono w tym zakładzie ${ }^{60}$.

Trzeba zdecydowanie podkreślić, że w ukraińskim porządku prawnym funkcjonuje organizacja o charakterze ponadwyznaniowym obejmująca jednak wyłącznie denominacje chrześcijańskie, tj. Ukraińska Misja Chrześcijańska w Miejscach Wykonywania Kary Pozbawienia Wolności. Koordynuje ona działania na rzecz zapewnienia opieki religijnej w zakładach karnych zwykłych, koloniach tzw. wyprawnych i koloniach dla młodocianych, a także w aresztach śledczych oraz współpracuje z władzami więziennictwa. Na przykład, 20 stycznia 2015 r. Misja odbyła doroczne spotkanie z udziałem dyrektora generalnego więziennictwa, podczas którego przypomniała swój aktywny lobbing w 2014 r. w Radzie Najwyższej na rzecz przyjęcia w pierwszym czytaniu projektu nr 1154 ustawy o duszpasterstwie więziennym ${ }^{61}$.

58 Zob. także Nikołajew 2015, 217.

59 www.risu.org.ua/ua/index/all_news/community/faith_and_weapon/56009 [dostęp: 7.11.2017].

${ }^{60}$ www.risu.org.ua/ua/index/all_news/community/religion_and_society/46623 [dostęp: 7.11.2018].

${ }^{61}$ Zob. Nikołajew 2016, 199. 


\section{ZAKOŃCZENIE}

Po uzyskaniu niezależności państwowej na Ukrainie podjęto działania zmierzające do usankcjonowania obecności duchownych w duszpasterstwie specjalnym. Głównie skoncentrowano się na duszpasterzach wojskowych, milicyjnych i więziennych obejmując szerzej także służby graniczne i celne. Jednak na przestrzeni ostatniego ćwierćwiecza widoczne jest wysokie zróżnicowanie aktywności organów państwowych oraz organizacji religijnych, a także pośród poszczególnych formacji militarnych i paramilitarnych oraz samych wspólnot religijnych. Stąd też kapelani wojskowi uzyskali odpowiednio wysoki status prawny potwierdzony właściwymi regulacjami ustawowymi i wykonawczymi (resort obrony narodowej) a „wymuszony” niejako sytuacją geopolityczną po rosyjskiej aneksji Krymu i separatyzmie wschodnich regionów Ukrainy. Dlatego też udało się przeprowadzić dość szybką (jak na ukraińskie warunki),,ścieżkę legislacyjną" i utworzyć struktury duszpasterstwa w ukraińskiej armii. W przypadku duszpasterstwa więziennego i policyjnego wykorzystano doświadczenia pochodzące z wojska i w zasadzie powielono rozwiązania tam przyjęte jako wzorcowe, nie uwzględniając jednak zobowiązań państwa w kwestiach etatowych i uposażeniowych. Także resort właściwy do spraw wojskowych podjął się organizacji szkoleń kapelańskich a wcześniej zorganizował struktury ministerialnej rady społecznej zajmującej się opieką religijną w wojsku. Poza aktywnością kościołów zabrakło jednak wsparcia ze strony administracji prezydenckiej, chociaż efektywnej pomocy udzielili deputowani wraz z przygotowanymi przez nich projektami aktów prawnych dotyczących zmian stosownych ustaw. W samych strukturach kościelnych utworzone zostały odpowiednie komórki (najczęściej wydziały) zajmujące się duszpasterstwem specjalnym łącznie z wyznaczonymi imiennie kapelanami. Sprawnie funkcjonujące struktury kapelańskie (głównie wojskowe i więzienne) utworzono w duszpasterstwie Ukraińskiego Kościoła Greckokatolickiego, Ukraińskiego Kościoła Prawosławnego Patriarchatu Kijowskiego, Ukraińskiego Kościoła Prawosławnego Patriarchatu Moskiewskiego oraz u ,rymokatolików”62, bap-

62 „Rymokatolicy” to popularne na Ukrainie określenie wiernych Kościoła Rzymskokatolickiego (obejmującego ok. 5\% społeczeństwa ukraińskiego). 
tystów i zielonoświątkowców. W organizacji duszpasterstw specjalnych wykorzystano także opinie pochodzące od przedstawicieli Wszechukraińskiej Rady Kościołów i Organizacji Religijnych (organu doradczego w sprawach wolności religijnej na Ukrainie) oraz Misji Chrześcijańskiej w Miejscach Wykonywania Kary Pozbawienia Wolności. Nie oznacza to jednak, że kapelani wojskowi, milicyjni i więzienni uzyskali pełne gwarancje państwowe stabilizujące teraz i w przyszłości ich posługę religijną w przestrzeni publicznej. Przeszkodą w tym zakresie może okazać się brak wypracowania modelu państwowej polityki wyznaniowej i zmieniająca się wciąż władza wykonawcza.

Nie udało się jednak zsynchronizować działań państwowych i kościelnych, i wprowadzić jednolitego ustawodawstwa państwowego. Brakuje przy tym ustalonych zasad relacji wzajemnych państwo-kościół. Nie uwzględniono także uwag przedstawicieli poszczególnych kościołów ani Wszechukraińskiej Rady Kościołów i Organizacji Religijnych. Dlatego słusznym wydaje się być postulat opracowania przepisów obowiązujących kapelanów duszpasterstw specjalnych na zasadach określonych przez państwo, ale uwzględniających słuszne potrzeby osób, do których to duszpasterstwo będzie adresowane. Nowe uregulowania mogą wpłynąć na poprawę stosunków państwo-kościół na Ukrainie i rozwiązać wiele problemów społecznych i gospodarczych oraz międzynarodowych (np. wciąż niezakończona wojna hybrydowa w Donbasie).

\section{BIBLIOGRAFIA}

Kohančuk, Ruslan. 2011. „Rol' kapelanstva u procesì vìdrodžennâ Zbrojnih sil Ukraïni na počatku 90-h rokì minulogo stolittâ". Vijsko Ukraïni 8(134): 2022 [Коханчук, Руслан. 2011. „Роль капеланства у процесі відродження Збройних сил України на початку 90-х років минулого століття”. Війско України 8(134): 20-22].

Kornelûk, B. 1998. „Vijs'ko i cerkva: ìstoriâ, problemi, perspektivi”. W: Vseukraïns'ka mižnarodna hristiâns'ka Asambleâ ,Zapovid' novu dâิ vam: lûbit' odin odnogo" (İoan,13,34). Naukovo-praktična konferencìâ, Kï̈, 1718 lûtogo 1998 r., red. Vasil' Turkevič. Kï̈v. [Корнелюк, В. 1998. „Військо і церква: історія, проблеми, перспективи”. W: Всеукраїнська міжнародна християнська Асамблея „Заповідь нову даю вам: любіть один одного” 
(Іоан, 13,34). Науково-практична конферениія, Київ, 17-18 лютого 1998 р, red. Василь Туркевич. Київ].

Kovalenko, Łesia. 2002. „Podstawowe regulacje wyznaniowe w prawie ukraińskim". Studia z Prawa Wyznaniowego 5: 79-109.

Kozyrska, Antonina. 2014. Pluralizm wyznaniowy a integracja narodu ukraińskiego po 1991 roku. Toruń: Europejskie Centrum Edukacyjne.

Nikołajew, Jerzy. 2015. „Wolność sumienia i wyznania więźniów na Ukrainie. Ujęcie prawne i socjologiczne". Nurt SVD 1: 211-234.

Nikołajew, Jerzy. 2016. Wspólnotowy wymiar wolności światopoglądu i przekonań religijnych oraz jej realizacja w ukraińskim systemie prawnym. Lublin: „Unitas” Wydawnictwo Diecezji Siedleckiej.

Pantelej, Kostântin. 2012. „Sučasnì risi krimìnal'no-vikonavčoï sistemi ta rol' penìtencìarnogo dušpastirstva". W: Služiti uv'âznenim. Fahovì oriêntiri dlâ dušpastirstvau penitenciarnih zakladah, 14-35. L'vìv: Vidavnictvo „Don Bosko” [Пантелей, Костянтин. 2012. „Сучасні риси кримінально-виконавчої системи та роль пенітенціарного душпастирства". W: Служсити ув'язненим. Фахові орієнтири для душпастирства у пенітенціарних закладах, 14-35. Львів: Видавництво „Дон Боско”].

S'omìn, Cergij. 2000. „Cerkva i armîa: partnerstvo či poglinannâ?”. Nacional'na bezpeka i oborona 10: 99-104 [Сьомін, Сергій. 2000. „Церква і армія: партнерство чи поглинання?”. Національна безпека і оборона 10: 99-104]. Vladičenko, Larisa. 2013. „İnstitut vìjs'kovogo kapelanstva v Zbrojnih Silah Pol'ŝ̀’”. Shid 5(125): 178-182 [Владиченко, Лариса. 2013. „Інститут військового капеланства в Збройних Силах Польщі”. Схід 5(125): 178-182].

Warzonek, Michał. 2014. Religion and Politics in Ukraine. The Orthodox and Greek catholic. Elements of Ukraine's Political System. Cambridge Scholars Publishing.

\section{THE STATUS OF CHAPLAINS OF SPECIAL CHAPLAINCIES IN THE UKRAINIAN LEGAL SYSTEM}

\section{Summary}

The Ukrainian military chaplaincy has the best developed organizational structures. This stems from the events of the Russian annexation of the Crimea and the hybrid war in Donbas. The prison chaplaincy has also been organized based on the structures of penitentiaries and detention centres. The police chaplaincy, in turn, requires the introduction of new legislative solutions. In addition, the Greek 
Catholic Church in Ukraine has established its own diocesan structures for special chaplaincies, whereas the remaining religious organizations have only organized rudimentary chaplaincies in the army, police and prison service.

The study concerns the functioning of the military, police and prison chaplaincies in Ukraine. The focus is the analysis of the legal regulations and practice in this respect, conducted using the dogmatic and comparative method. The aim is to suggest some possible legislative solutions, which would for example consist in issuing state regulations that guarantee religious care in the form of special chaplaincies. The article concludes with some suggestions and recommendations along these lines.

Key words: chaplains; special chaplaincy; religious freedom; military chaplaincy; Ukrainian legal system; freedom of conscience and religion; Church-State relations

Ttumaczenie: Daria Bębeniec 